\title{
A nyugat-mongóliai dzahcsinok és népdalaik rövid ismertetése
}

\section{Előszó}

Jelen tanulmány célja az ELTE Belső-ázsiai Tanszék és jelenlegi jogutódja, a Mongol és Belső-ázsiai Tanszék által szervezett számos expedíció, különösen a nyugat-mongóliai terepmunka folytatása, illetve az ott gyüjtött néprajzi és folklóradatok feldolgozása. ${ }^{1}$ A Mongólia nyugati felén, a fővárostól mintegy 1500 kilométerre elhelyezkedő Hovd megye területén fekvő apró Altaj járásba (halha sum) ${ }^{2}$ részben a 2014 őszén Cahiagín Elbegdordzstól, Mongólia elnökétől kapott ösztöndíjnak köszönhetően jutottam el 2015 nyarán. A néhány ezer ${ }^{3}$ lelket számláló, tisztán dzahcsinok (halha jaxčin, ojr. zaxčin, jaxčin) lakta településen végzett kutatómunka során többek között egy idős népdalénekessel, Cs. Dügerszürennel (Č. Dügersüren) készítettem interjút, aki maga is népdalgyüjtő, és e tevékenysége során 1992-ben kiadott egy rövid népdalgyüjteményt is. ${ }^{4}$ Írásom gerincét az általa leírtak és elmondottak képezik, melynek rögzítésében, illetve a dalok fordításában Pilden Tungalag volt segítségemre, míg e munka végső változatát Birtalan Ágnes segítségével sikerült befejezni.

Mivel a téma csak most kezdett el foglalkoztatni, itt csupán egy jövőbeli, nagyobb szabású, összefoglaló jellegű munka előképét kívánom felvázolni, a teljesség igénye nélkül. A népdalok fordításán és ismertetésén kívül a dzah-

$1 \quad$ Az expedíció útvonalát részletesen lásd Birtalan 2012: 90. Tanulmányomhoz általános háttérként szolgáltak a következő müvek: Batubayar 2013, Birtalan - Rákos 2002, Kara 1998.

2 „Járás”, „nyílvessző” (mong. sumu). Mandzsu kori adminisztratív egység, mely az egykori otogokat (mong. oto $\gamma$ ) váltotta fel. Napjainkban gyakorlatilag egy faluból és a körülötte távol, szétszórtan elhelyezkedő jurtákból álló közigazgatási egység.

3 A pontos szám körülbelül háromezer före becsülhető, azonban erről a megkérdezettek nem tudtak egybehangzó, egyértelmű választ adni.

4 Dügersüren 1992. 
csin nemzetség egyedülálló eredetét és történelmét kívánom az olvasó elé tárni, míg az általuk beszélt nyelvről és a kultúra más elemeiről csak érintőlegesen írok.

\section{A dzahcsinokról és történelmükről}

A dzahcsinok nagyállattartó, lovas nomád kultúrája hasonló a többi mongol, vagyis föként a legnagyobb számú halha (halha xalx) népcsoport anyagi és szellemi mủveltségéhez, bár kisebb eltérések megfigyelhetők. Mivel történelmük során a nyugati mongolok, vagyis az ojrátok (halha oyird, ojr. $\bar{o} r d$ ) voltak rájuk a legnagyobb hatással, nyelvüket is ojrátnak tekinthetjük, még akkor is, ha ma föleg a mongol köznyelvként elfogadott halha gyakorolja rá a legerősebb hatást. ${ }^{5}$

Eredetük vizsgálatát az ojrátok történelmével érdemes kezdeni, akiket a 13. századig a Bajkál-tó partján élő erdei népekként (mong. hoi-yin irgen) emlegetnek a források. Később az Altaj-hegység vidékére vándorolva felvették a sztyeppei életmódot, és hatalmuk a Dzsungár Kánság 17-18. századi megalapításával teljesedett ki, ${ }^{6}$ ami a birodalom mandzsuk általi meghódításával ért véget a 18 . században. ${ }^{7}$

A dzahcsinok megnevezése az általuk végzett határőr tevékenységből ered, vagyis a mongol „határ, szél, szegély, perem” jelentésű jax szóból és a hozzá toldalékként kapcsolódó čin foglalkozásképzőből tevődik össze.

Valószínünek látszik, hogy elöször a dzsungár Galdan Bosogt kán (mong.

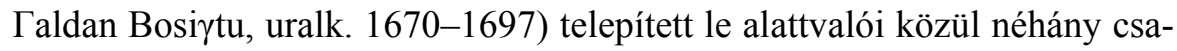
ládot az ország délkeleti határán, az Erén Havirga területén az 1670-es években. A 17. század első felében tehát a dzahcsinok a Dzsungár Kánság e határát őrizték, melynek mentén a Tenger-hegy északi oldalán, az Erén Havirga, az Ih Dzsultasz, a Baga Dzsultasz, valamint a Bulingar-, Bulgan-, Csingel- és Öröngö-folyók, továbbá a Cagán tohoj területén éltek.

A dzahcsin nép a század végén a kánság területén lévő húsz önálló otog ${ }^{8}$ egyikében élt. Mivel ekkor a határőrizetet különös jelentőséggel bíró tevé-

Birtalan 2008: 27-28.

Birtalan 2005: 210.

Kara 2005: 137.

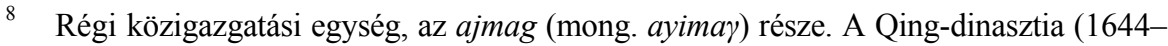
1911) korában a mandzsuk szumokra és hosúnokra (mong. qoriłun) változtatták. 
kenységként kezelték, az akkoriban több mint kétezer családot számláló dzahcsin otog nem egy helyi nojon (halha noyon) ${ }^{9}$, hanem közvetlenül a kán irányítása alatt állt. A kán nevében az általa kinevezett három dzajszan (mong. jayisan $\gamma$, ojrát zaisan ${ }^{10}$ járt el. Az otog negyven embert tömörítő, albacs (halha $a l b a c^{11}$ ) által vezetett negyvenedekre volt tagolva, azokat pedig további huszadokra osztották fel.

A határ örzése mellett az itt élő nép feladata volt a természetbeni adózás is, melyet a telenként elejtett vadak beszolgáltatásával, illetve a helyi kolostorok élelmezésével, vagyis élő lábasjószág küldésével egyenlítettek ki. Ezenkívül katonai szolgálatot teljesítettek háború idején, illetve követként idegen országokba is küldhették őket.

A Dzsungár Birodalom végét a mandzsu támadás jelentette a 18. század közepén, mely a dzahcsinokat, különösen a dzsungár-halha határ mentén élőket érte el legelőször. Mamud dzajszant 1754 végén fogták el, és telepítették le Dzajlgan vidékén, majd a következő év nyarán szintén fogságba esett Dondog és Mandzs is, akiket az Erén Havirga vidékére telepítettek át, összesen mintegy 1500 családnyi alattvalóikkal együtt. Ezen felül 1755-ben a mandzsuk a régi negyvenedeket alapul véve egy hosúnba (halha xošūn ${ }^{12}$ ) és kilenc szumba tagolták be a dzahcsinok népét. A határörök zöme, akik egykor Dondog és Mamud szolgálatában álltak, Amarszana ${ }^{13} 1755$. szeptember 24-én kezdődö ${ }^{14}$ harcát támogatva ellenállt a mandzsu hódításnak, amiért utóbbiak tüzzel-vassal irtani kezdték őket, a kevés túlélőt pedig rabszolgának küldték a kínai Shanxi 山西 tartományban állomásozó katonáknak és a hadsereg parancsnokainak. Ezen felül 1756-ban a túlerőnek ellenállni képtelen, mintegy 2100 elfogott Galdzad otogbeli családot költöztettek át Hölön és Bujr vidékére, ahol hosúnba és szumba tagolták be őket, míg néhány más családot a Cahar- és a Har-folyók vidékén osztottak szét. 1756-ban mind a kilenc, korábban el nem ismert dzahcsin szum vezetőjeként Dzsamcan megkapta a hatalmat jelentő pecsétet, mellyel elismerték a településeket.

9 „Nemesúr, herceg vagy parancsnok”.

10 Mandzsu kori hivatalnoki rang.

11 Mandzsu kori hivatalnoki rang.

12 „Zászló”. Kínában még ma is létező, egykori mongol közigazgatási egység, mely az ajmag részét képezi.

13 Amarsana (1722?-1757) Qing hadvezér volt, aki elöször a Dzsungár Birodalom ellen harcolt, de később a mandzsu Qing-dinaisztia ellen fordult.

14 Baabar1999: 91. 
A harcok végére a dzsungáriai dzahcsin otog kétezer körüli családjának nagy részét lemészárolták, a maradék pedig különböző helyekre szóródott szét. Azon hatszáz család tagjait, akiket az egykori halha határ mentén szolgálatot teljesítve először ért a csapás, 1754-től az Uliastajban lévő mandzsu helytartó (mandzsu/kínai nyelvből származó mongol formája: janj̄) igazgatása alá rendelve, Hovd délnyugati részén telepítették le. A Hovd déli felén letelepítettek 1777-töl a hozzájuk közelebb lévő hovdi helytartó alá tartoztak.

Ugyanebben az évben meghalt Mamud unokája, Dzsamcan, akit egy évvel később fia, Mendesid követett güngként ${ }^{15}$ az uralkodásban. Hatalomra kerülésével párhuzamosan az ö vezetésével alakították meg azt a hondogo szumot (halha xondogo sum ${ }^{16}$ ), melynek harminc családnyi lakosságát Mamud egykori alattvalói közül választották ki. A mandzsuk terjeszkedése után a közigazgatási egységeket jelentősen átalakították, amiből megszületett a hondogo szum és a bügdin dargín hosún (halha bügdīn dargīn xošū). Amikor később a güng alattvalóinak száma 150 család fölé emelkedett, 1800-ban önálló szumot hoztak belölük létre, és vezetőik, Mamud és Dzsamcan korábbi, mandzsu uralom előtti érdemeire való tekintettel mentesítették őket az országos szintủ adófizetési kötelezettség alól. ${ }^{17}$

Ebben az évben jelentette továbbá a hovdi helytartó a terület ügyeit intéző minisztériumnak, hogy a dzahcsin bügdín darga ${ }^{18}$ számára réz pecsétet juttatott, és megbízta a hosún irányításával. Ekkor a dzahcsin güng és a bügdín darga a hovdi mandzsu helytartó alá tartozó többi - dörböt, urjanhaj, torgut, és mjangat - hosún vezetőivel együtt felváltva élt Hovdban, ahol megtanulták a hosún ügyeiben való döntéshozatalt, és megismerkedtek a mandzsu joggal, valamint az állami feladatok elvégzésével. A miniszterek ezáltal hathónapos periódusokban váltották egymást, és Hovdban laktak, ahol a dzahcsin güng a tél középső és utolsó hónapjában élt.

Miután a dzahcsinok közül 1755-ben besorozott háromszáz lovas a mandzsuk oldalán részt vett Dzsungária elfoglalásában, további szolgáltatások teljesítésére kötelezték őket. Ilyen volt például az évente meghatározott számú ló beszolgáltatása az Uliastajban állomásozó katonai ménesbe, illetve a hadsereg Hovd környéki termőföldjein való kötelező munkavégzés is. Ezen-

15 Mandzsu kori förang.

16150 katonát kiállítani nem tudó, kisebb, úgynevezett „fél sum”.

17 Mahmud és Dzsamcan tevékenységéröl lásd Birtalan 1985.

18 A dzahcsin területek vezetője, mandzsu kori rang, jelentése: „mindenek vezetője”. A cím - a források szerint - örökletes volt, erröl részletesen lásd Birtalan 1985: 177-203. 
kívül az őlötök, mjangatok és dzahcsinok közül került sorozásra a Hovd városát védő száz katona is. 1801-ben a Hovd városából kiinduló út menti nyolc lovasposta-állomás eredetileg halha személyzetét is a közülük kiállított nyolcvan családnyi katonára cserélték le. Ugyan Hovdból évi nyolc $\operatorname{lan}^{19}$ ezüst támogatást kellett kapnia minden egyes postaállomásnak az áthaladó utazók élelmezésére, ez gyakran kevésnek bizonyult, így a dzahcsinok maguk voltak kénytelenek a költségeket fedezni, valamint az állomás számára biztosítani a lovakat és egyéb szükséges felszereléseket.

Amikor a mandzsu Qing-dinasztia bukását kihasználva Mongólia 1911ben újra önállóvá vált, a két dzahcsin hosún, melyek teljes népessége ekkor mintegy 4800 fö volt, a dörböt Ünen Dzorigt kán megye irányítása alá került. 1912-ben a mongol kormány a bügdin dargín hosún vezetőjének a güng címet adományozta, melynek átörökítése is lehetővé vált ekkortól. Ezzel párhuzamosan az egykori güngín hosún első embere a bejl címben részesült. Ettől az időtől fogva kezdték el az északi dzahcsin hosúnt Dzahcsinszecen güngín hosúnnak, míg a délit Bejlín hosúnnak nevezni. Az egykori, egy szumból álló mandzsu korabeli güngín hosún ma a Hovd megyei Üjencs szum, míg a négy szumból álló bügdín dargín hosún a jelenlegi Manhan, Dzereg, Möszt és Altaj szumok, ahol a dzahcsinok ma is megtalálhatók. ${ }^{20}$

A dzahcsin nép etnikai összetételét és eredetét máig nem sikerült teljes biztonsággal meghatározni. Az orosz utazó és kutató, G. N. Potanin a dzahcsinok között sangasz, bügünüd és kirgisz nemzetségek jelenlétét jegyezte le, valamint kifejtette azon véleményét, mely szerint a dzahcsinok se nem halhák, se nem torgutok, mivel szokásviláguk leginkább a dörbötökével egyezik meg. G. E. Grumm-Grzsimajlo a dzahcsinok nemzetségének összetételét vegyes jellemzőkkel bírónak írta le, köztük pedig az ojrátokon kívül urjanhaj, mjangat, kirgisz, és telengú nemzetségeket figyelt meg. Dzs. Cevén és D. Gongor feljegyzései szerint a dzahcsinok szokásvilága a torgutokéval mutat hasonlóságot, ezért tőlük szakadhattak el. A Belső-ázsiai Tanszék egykori vendégtanára és kutatóútjainak aktív résztvevője ${ }^{21}$, Dzs. Coló (J̆. Colō) helyi öregektől érdeklődve írta le, hogy a dzahcsinok közt dörbötökön és torgutokon kívül még halhák vannak jelen.

19 Kínai súlymérték, 37,3 grammnak felel meg.

20 Badamxatan 1996: 334-338.

21 Birtalan 2004: 51. 
Ami a mai állapotot illeti, a 2010-es népszámlálás adatai szerint a dzahcsinok Mongólia lakosságának 1,2\%-át teszik ki, és pontos lélekszámuk 32845 fö, mellyel a hatodik legnagyobb mongóliai népcsoportnak tekinthetők. A hivatalos statisztikák szerint számuk - Mongólia össznépességével párhuzamosan - folyamatosan növekszik, ${ }^{22}$ amit jól mutat a kedvezö korfa is: a dzahcsinok 51,2\%-a 24 év alatti fiatal, míg a 45 évesnél idősebbek aránya mindössze 19,1\%-ot tesz ki. Az eredetileg csak Hovd megyében élő népcsoportnak 2010-ben csupán 60,3\%-a volt megtalálható eredeti lakóhelyén, míg népességük 26,2\%-a (az országos trendet követve) a fővárosba költözött. Jelentős csoportjaik élnek még ezen kívül a fơvárostól északra és északnyugatra, az orosz határ melletti Szelenge, Orhon és Darhan-Úl megyékben is. Vallásukra a muszlim kazahok közelsége nem volt befolyással, mivel a vallásgyakorlók túlnyomó többsége buddhistának vallotta magát, míg a muszlim hívők százalékos aránya nulla. ${ }^{23}$

\section{A dzahcsin népdalok}

A mongol, és ezen belül is a dzahcsin népdalok (halha ardin dū) gyüjtésében és kutatásában az ELTE Mongol és Belső-ázsiai Tanszéke már régóta aktív szerepet vállal. Magyarul - valamint más, idegen nyelveken - Dr. Birtalan Ágnes munkái olvashatóak, aki többek között kandidátusi disszertációjában foglalkozik a párhuzamos szövegek részletes elemzésével. ${ }^{24}$ Mongóliában gyakran publikált témáról beszélhetünk, ami szintén kapcsolódik a Tanszékhez, mivel a korábban már említett egykori vendégtanár, Dzs. Coló jelentetett meg a nyolcvanas évek végén egy ojrát dalgyüjteményt, ${ }^{25}$ illetve az ojrát nyelvjárás szótárát, ${ }^{26}$ melynek magam is nagy hasznát vettem a dalok fordításakor. Példáját az ezredforduló után az ELTE volt nyelvi lektora, B. Kató (B. Katū) követte, aki társszerzőként 2004-ben írt a dzahcsin népköl-

22 A dzahcsin népesség száma közel 8000 fő volt 1929-ben, 10800 fö 1956-ban, és 22500 fö 1989-ben. Részletekért lásd Atwood 2004:617.

23 Xün am, oron sūcnī 2010 onī ulsīn tōllogo: negdsendün.’BCI” Xevlelīn kompani, Ulānbātarxot, 2011 on, 51-63.

24 Birtalan 1992.

25 Colō 1987.

26 Colō 1988. 
tészetről, ${ }^{27}$ majd 2005-ben kiadta önálló monográfiáját is a dörböt ünnepi és rövid népdalokról. ${ }^{28}$

Mivel a népdalok esetében a mongol líra leggazdagabb müfajáról van szó, nem csoda, hogy számos dalt a mai napig is énekelnek, és ezeknek több, egymástól kisebb vagy nagyobb mértékben eltérő változata ismert. A népdaloknak alapvetően két típusa különböztethető meg. A legkedveltebb a hosszúdal (halha urtīn $d \bar{u}$ ), mely rendszerint emelkedett stílusban kerül elöadásra, témája pedig jellemzően a szülőföld, a szülők, a kedves vagy a Mongóliában jelen lévő tibeti eredetű buddhista vallás. A legtöbb kutató által használt belső keletkezésü, émikus műfaji besorolás szerint az előadás módját tekintve a röviddal (halha bogino dū) képezi a másik, kisebb mértékben elterjedt népdaltípust. Ennek előadásmódja kevésbé magasztos, annál inkább vidám, pörgös. ${ }^{29}$

A népdalokat szokás még tematikájuk szerint is besorolni, ami a hoszszúdalok kapcsán már említésre került. A szülöföldről és anyáról szóló dalok mellett jellemzőek még a történeti énekek, a rokonokhoz szólóak, valamint a jó ló képe is igen kedvelt téma. A dalokat az előadás ideje is meghatározhatja, mivel a nem kötöttek mellett léteznek ünnepkezdő és ünnepzáró énekek is.

A mongolok többségéről elmondható, hogy kiváló énekes, mely tehetségüket elöszeretettel meg is mutatják mind a hétköznapokban, mind a médiában. A mongol népdalok, illetve a hozzájuk hasonló, sokak számára nem megkülönböztethető müdalok rendkívül népszerüek, így az ország végtelen pusztáit vagy városait járva nap mint nap bárhol hallhatók.

A mongol népdalok közös jellemzője, hogy a hagyományosan négy-, ritkábban kétsoros versszakok elején található az elörím, de ragrím is gyakran megfigyelhető. A párhuzamos szerkesztést és a gondolatritmust jól példázza a külső és belső kép váltakozása, vagyis a dal elején használt természeti kép gyakori párhuzamba állítása az anyával vagy éppen a kedvessel. Az első sor szinte minden esetben a dal címét is jelenti, de ez néha az első két sorról mondható el. ${ }^{30}$

A dalok a versszakok témája szerint gyakran elemekre bonthatóak, mely elemek több dalban is megjelenhetnek, különbözö összeállításokban is. Az

27 Katū - Pürewjaw 2004.

28 Katū 2005.

29 Részletes müfaji elemzés: Birtalan 1992.

30 Bőveben lásd Birtalan 1992. 
alább idézett Szürkésfehér ló címü dalban például a ló és a vörösfenyő képe követi egymást néhány versszak erejéig. A mü e két eleme könnyen megjelenhet más dalokban, más témákkal együtt, vagyis a szakaszok különösebb megkötések nélkül cserélődhetnek az egyes változatokban. Az egyes szakaszokat a versszakok utolsó egy vagy két sorában található refrén teszi hasonlóvá egymáshoz, melyek szintén cserélődhetnek a dalok különböző változataiban.

A mongol nyelven olvasható énekek esetében megfigyelhetö, hogy a sorok szótagszáma sok esetben nem azonos, s ezt a különbséget az énekes az egyes szótagok megnyújtásával egyenlíti ki. Az énekeket gyakran kísérik a kéthúros lófejes hegedủvel (halha morinn xūr), illetve az ojrátoknál a tovsúr (ojr. towšūr) nevü, háromhúros pengetős hangszerrel, ${ }^{31}$ melynek említése esetenként magában a dalban is megfigyelhető. Ezenkívül számos motívum jelenik meg a müvekben, mint például az egyre növekvő számok, úgymint száz, majd ezer, később pedig már akár tízezer drágakő vagy istenség említése.

Az eredeti mongol népdalok előrímes sorkezdésének hangzását a magyar fordításban gyakran nem lehetséges hủen visszaadni, ennek ellenére törekedtem arra, hogy az alábbi daloknál megőrizzem a szókezdő hangokat. Az általam is lefordított dzahcsin népdalok a halha nyelv mellett nem ritkán tartalmaznak archaikus, a mai beszélt és írott nyelvben már nem használatos kifejezéseket és ragokat, illetve nyelvjárási szavakat. A mongol nyelv sajátosságaként továbbá gyakran megjelenek olyan szavak, melyeket magyarul több másikkal lehetne csak megmagyarázni. Az ilyen esetekben lábjegyzetben adom meg az adott szó pontos jelentését.

A következőkben az expedíción összegyüjtött népdalok közül a legfontosabbakat kívánom mind eredeti formájában, mind magyar fordításban közölni.

\section{Nyolcszigetü Szümerü-hegy ${ }^{32}$}

Nyolcszigetü Szümerü-hegy

Nap és Hold az éke.

Örök életre összekapcsolódva született

A damba és a vallás. ${ }^{33}$

\section{Naiman tiwtei sümber ūl}

Naiman tiwtei Sümber ūl

Nar saran čimegtei.

Nasan ürgelǰde barildan törsön

Damba šajin xoyor.

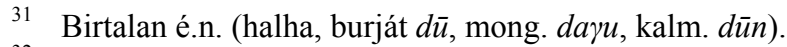

32 A mongol eredetmagyarázó történetekben és egyéb mítoszokban gyakran feltünő, szanszkrit eredetü világhegy, eredetileg Jud. Bővebben lásd Birtalan 2001.

33 Népdalokban a vallással együtt gyakran emlegetett, egyelöre pontosan nem ismert eredetü kifejezés. Bővebben lásd Birtalan 2008: 30-31. 
A déli nagy forróságban

Harmadfü rőtemmel ügetek.

Örökre összekapcsolódva született

A damba és a vallás.

Aszály delén a forróságban

Csinos szépségủ rőtemmel ügetek.

Szomorúvá lett szívemet

Acél zárral szorítom.

Csapkodni kezdő tetőnemezt

Lószőr szíjjal lekötözöm.

Belül remegni kezdő szívet

Nyugodtság zárjával szorítom.

Gyürődni kezdő tetőnemezt

Kender szíjjal lekötözöm.

Összeszorulni kezdő szívet

Bölcsesség zárjával szorítom.

Lobogni kezdő tetőnemezt

Lószőr szíjjal lekötözöm.

Dobogni kezdő szívet

Szigor zárjával szorítom.

Épületnek nevezett jurtát

Az oszlop javával építem.

A kicsit nagyon, ha tisztelek

Jó esze által tisztelem.

Sátorkunyhónak nevezett jurtát

A tetőrúd javával építem.

Erősnek nevezett rokoni kapcsolatot

Jó esze által tisztelem.

Sátorkunyhónak nevezett jurtát

A tetőgyürü ${ }^{34}$ javával építem.

A mindenki által felmagasztaltnak nevezettet

Jó esze ésszel tisztelem.
Üdēn ix xalūnd ni

Ürē šig jērdērē galigūlna.

Ürēn ürgeljuid barildan törsön

Damba šajin xoyor.

Gan üdēn xalūnd ni

Gangan šig jērdērēe galigūlna.

Ganslād irsen jürxīg mini

Gangīn cōjōr darna.

Deweljēd irsen dēwrīg

Dēsen argamjār darna.

Denslēd irsen jürxīg

Denčìn cōjōr darna.

Owoljōd irsen dēwrīg

Olson argamjār darna.

Owoljōd irsen jürxīg

Ončīn cōjōor darna.

Xīsēd irsen dēwrīg

Xyalgasan argamjār darna.

Xiwšēd irsen jürxīg

Xīgìn cōjōr darna.

Baišin gedeg gerīg

Baganīn sainār barina.

Baga ixē xündelne gedeg

Uxānī sainār xündelne.

Urc gedeg gerīg

Unin̄̄ sainār barina.

Urag törlö xündelne gedeg

Uxānī sainār xündelne.

Xatgūr gedeg gerīg

Xarācīn sainār barina.

Xamag olnō xündelne gedeg ni

Uxānī sainār xündelne.

34 Mivel az említett típusú sátornak a tetőgyürü nem eleme, lehetséges, hogy a dalokban gyakran megfigyelhető szövegromlásról van szó. 


\section{Helyes fakó ló ${ }^{35}$}

Helyes fakó ló

Horhos folyóján átkel $d z s a a$.

Helyes alkatú szentet

Aranyos trónusra hívjuk, dzsaa.

Nyúlánk fakó ló

Nádám helyén átmegy $d z s a a$.

Nem egész nyolc hibás fenségeset

Aranyos trónusra hívjuk, $d z s a a$.

Aranyos szájú fuvola

Sátorpalota felett játszik $d z s a a$.

Megváltó nagy szentet

Aranyos trónusra hívjuk, dzsaa.

Ezüst szájú fuvola

Folyam felett játszik $d z s a a$.

Örökkévaló földre szállt szentet

Aranyos trónusra hívjuk, dzsaa.

\section{Magas Bogd csúcsa ${ }^{36}$}

A magas Bogd csúcsán

hajnali nap jön fel.

Gondoskodó anyámat

Mostan felkeresem.

Terebélyes szantálfán

Szarka madár cserreg.

Szívélyes anyámat

Mostan felkeresem.

Bömbölő oroszlán

Morogva, hörögve szól.

Gondoskodó anyámat

Mostan felkeresem.

Erős sas

Zúgva, zengve vijjog.

Törődő anyámat

Mostan felkeresem.
Xörxön šarga mori

Xörxön šarga mori ni

Xöndīn golōr tūlna jāa.

Xörxön dürtei bogdīg

Altan širēndē jalnā jă

Narīn šargal mori ni

Nādmīn talbaid tūlna jāa.

Naimxan ötei bogdīg

Altan širēndē jalnā jāa.

Altan amtai bišgürīg

Asrīn dēgür tatna jāa.

Awralīn dèd bogdīg

Altan širēndē jalnā jāa.

Möngön amtai bišgūrīg

Mörön dēgür ni tatna jāa.

Mönxīn xuwilgāntai bogdīg

Altan širēndē jalnā jă

\section{Öndör bogdōn orgil}

Öndör bogdōn orgild

Örünī naran mandana.

Örgömǰ saitai ējde

Odō bi čini jolgono.

Saglagar jandan modond

šājgai šuwū šagšina.

Saixan jantai ējteigē

Odō bi čini jolgono.

Am ixtei arslan

Arjignan arjignan dūgarna.

Asramǰ saitai ējteigē

Odō bi čini jolgono.

Xüč ixtei bürged

Xüngenen xüngenen šūgina.

Xünleg saitai ējteigē

Odō bi čini jolgono.

35 Párhuzama: Birtalan 1992.

36 Párhuzama: Birtalan 1992. 
Roppant szárnyú sas

Mély hangon vijjog.

Hetvenet elért anyámat

Mostan felkeresem.

Erős szárnyú sas

Éles hangon vijjog.

Boldogságban teljes anyámat

Mostan felkeresem

\section{Hán-hegy csúcsa ${ }^{37}$}

Hán-hegynek csúcsán

Füstáldozat füstje gomolyog.

Hatalmas jáde templomban

Mécses világa pislákol.

Arasszal mérve épített

Kerek sárga szentély.

Töölört ${ }^{38}$ és bünt

Lámák, nekem kedvesek, rátok bízom sorsom.

Mintásra épített

Kolostor arany szentélye.

Vétket és bünt

Lámák, nekem kedvesek, nektek meggyónom.

Öllel mérve épített

Aranyos sárga szentély.

Veszélyt és bünt

Lámák, nekem kedvesek, rátok bízom sorsom.

Szorgalmas lámatanítvány

Nyolcadik évét elért.

Ecset szavát tanulva

írnoki rangra talál.

Jó miniszter gyermeke

Kilencedik évét elért.

Ecset szavát tanulva

Tudós rangjára talál.
Dalawč ixtei bürged

Daǰignan daǰignan šūgina.

Dal xürsen èjteigē

Odō bi čini jolgono.

Jiwer ixtei bürged

J̌ingenen juingenen šūgina.

Jargalīn dēd ējteigēe

Odō bi čini jolgon

\section{Xan ülīn oroi}

Xan ūlīn oroid

Sangīn utā manarna.

Xaš ix dugand ni

Julān gerel todorno.

Töly barisan

Tögrög šar süm.

Tōlör nügel xoyorīg

Lam tandā dātgaya.

Xēlj barisan

Xìdīn altan süm.

Xilenc nügel xoyorīg

Lam tandā ailtgan.

Aldalj barisan

Altan šar süm.

Ayūl nügel xoyorīg

Lam tandā dātgaya.

Sain lamīn šawi

Naiman nas xürēd.

Bīr bičgē surād

Bičéčìn colìg olno.

Sain saidīn üren

Yesön nas xürēd.

Bīr bičgē surād

Erdemten colō olno.

37 Párhuzama: Birtalan 1992 és 2008.

38 A szó jelentését a dolgozat befejezéséig nem sikerült megfejteni. 
Hattyú fiókája

Szárnytolla kinő.

Három tengeren túljutva

Madarak címére talál.

Vadszamár és vadló csikaja

Kerekded patája kinő.

Három folyón átkelve

Gyorsan rangra lel.

\section{Lótusz magaslat argalija ${ }^{39}$}

Lótusz magaslat argaliját

Kicsiny deres lovon űzöm.

Kitartó kevély nénémet

Hogyan tudnám feledni?

Vizes bérc argaliját

Postalóhoz fogható deres lovon hajtom.

Nyugodt természetü nénémet

Hogyan tudnám feledni?

Hófedte meredély argaliját

Oltott tej színü deres lovon üzöm.

Jóindulatú nénémet

Hogyan tudnám feledni?

Jeges csúcs argaliját

Ezüst színü deres lovon hajtom.

Szelíd nénémet

Hogyan tudnám feledni?

Bazalt kőszál argaliját

Gesztenyebarna deres lovon üzöm.

Emberséggel törődő nénémet

Hogyan tudnám feledni?

Sziklaorom argaliját

Halovány feketés deres lovon hajtom.

Nagylelkủ nénémet

Hogyan tudnám feledni?
Xun cengīn juljgan

Öd jiwerē güicēj.

Gurwan dalai gatlaj

Jigürrten colō olno.

Xulan taxīn unaga

Xumban tūraigā güicēj.

Gurwan golīg gatlaj

Xurdan colō olno.

\section{Badam xamrīn argali}

Badam xamrīn argalīg

Bagašig borōr namnana.

Bat jantai ākīg

Alixan nasandā martax we?

Ust xamrīn argalīg

Ulā šig borōr namnana.

Uyaxan jantai ākīg

Alixan nasandā martax we?

Cast xamrīn argalīg

Cagā šig borōr namnana.

Cailgan jantai ākīg

Alixan nasandā martax we?

Möst xamrīn argalīg

Möngönšig borōr namnana.

Mönx jantai ākīg

Alixan nasandā martax we?

Xüremt xamrīn argalīg

Xürenšig borōr namnana.

Xünleg jantai ākìg

Alixan nasandā martax we?

Xadat xamrīn argalīg

Xarxan borōr namnana.

Xailgan jantai ākīg

Alixan nasandā martax we?

39 Vadjuh (Ovis ammon). Párhuzama: Birtalan 1992. 
Erdős tető argaliját

Kékes deres lovon üzöm.

Kedves nénémet

Hogyan tudnám feledni?

\section{Barnás Altáj}

Barnás Altájba

Tavasz melegsége érkezik.

Számos fivéremmel

Vigadva együtt boldogok vagyunk.

Hegyháton nyári szállás

Hűvös csodás Altáj.

Színarany fivérimmel

Vigadva együtt boldogok vagyunk. ${ }^{40}$

Hegy tetején nyári szálláshely

Széles szép Altáj.

Számos szerető fivéremmel

Vigadva együtt boldogok vagyunk.

Szomszédos hegy csúcsán tavaszi szálláshely

Tágas széles Altáj.

Szerető számos fivéremmel

Vigadva együtt boldogok vagyunk.

Déli oldalán téli szálláshely

Magas szép Altáj.

Népes számos fivéremmel

Vigadva együtt boldogok vagyunk.

Hegy nyergén őszi szálláshely

Napfényes széles Altáj.

Korban magas fivéremmel

Vigadva együtt boldogok vagyunk.

Madárbirs nevü fa

Jataga $^{41}$ húrmerevítője lesz.

Egyazon apánk fivéreim

Jaj, de messze vagytok.
Xöwčit xamrīn argalīg

Xöx borōr namnana.

Xörxön jantai ākīg

Alixan nasandā martax we?

\section{Jüslentei Altai}

Jüslentei Altaid

Xawrīn uri orno.

Jüilīn olon ax nartaig $\bar{a}$

Nairlan xamt jargana.

Šilīn dēgür juslantai

Serün saixan Altai.

Šijrīn olon ax nartaigā

Nairlan xamt jargana.

Ūlīn dēgür juslantai

Ujim saixan Altai.

Ulsīn olon ax nartaig $\bar{a}$

Nairlan xamt jargana.

Xajū dērē xawarjāntai

Xanagar ūdam Altai.

Xairtai olon ax nartaig $\bar{a}$

Nairlan xamt jargana.

Öwör dērē öwöljōōntei

Öndör saixan Altai.

Önör olon ax nartaigā

Nairlan xamt jargana.

Naxiu dērē namarjāntai

Narlag ūdam Altai.

Nasan öndör ax nartaigā

Nairlan xamt jargana.

Yargai gedeg mod

Yatgīn tewx bolno.

Yasnī törlīn ax nar

Yāsan xol sūdīm.

\footnotetext{
40 A mủ első két versszakát a forrás egybefoglalva közli, ami - a mongol népdalokat ismerve, illetve az itt idézetteket figyelembe véve - egyértelműen hibás, és nem az eredeti alakot tükrözi.

41 Citeraszerü pengetős hangszer.
} 
Nyárfa nevü fa

Tovsúr ${ }^{42}$ húrmerevítóje lesz.

Szük családom utódai

Jaj, de messze vagytok.

Cédrus nevü fa

Hegedű húrmerevítője.

Hosúnbéli családom utódai

Jaj, de messze vagytok.

Kecskerógó $^{43}$ nevü fa

Ekel $^{44}$ vonója szokott lenni.

Családom fiai

Jaj, de messze vagytok.

\section{Három folyó forrásánál}

Három folyó forrásánál

Harmadfü paripám legeltetem.

Harmincat betöltött anyámnál

Háromszor örömtelien találkozunk.

Négy folyó forrásánál

Négyéves paripám legeltetem.

Negyvenet megért anyámnál

Négyszer örömtelien találkozunk.

Öt folyó forrásánál

Gerle lovam legeltetem.

Ötvenet elért anyámnál

Ötször örömtelien találkozunk.

Hat folyó forrásánál

Hatéves paripám legeltetem.

Százéves anyámnál

Hatszor örömtelien találkozunk.
Tōroi gedeg modon

Towšōrin tewx boldog.

Dotno xünī ür čini

Yāsan xol sūdìm.

Xuš gedeg modon

Xūrīn tewx boldog.

Xušū xünī ür čini

Yāsan xol sūdìm.

Emgelǰ gedeg modon

Exelīn xöwč boldog.

Ewrīn xünī ür čini

Yāsan xol sūdìm.

\section{Gurwan golīn exend}

Gurwan golīn exend

Gunataixan agtā xariulna.

Guč xürsen ējdē

Gurwan bayartai jolgono.

Dörwön golīn exend

Dönöteixen agtā xariulna.

Döč xürsen ējdē

Dörwön bayartai jolgono.

Tawan golīn exend

Tagtā šig agtā xariulna.

Tawi xürsen ējdē

Tawan bayartai jolgono.

Jurgān golīn exend

Jurgātai agtā xariulna.

Jū xürsen èjde

Jurgān bayartai jolgono.

42 Hosszú nyakú, háromhúrú, pengető hangszer.

43 Faanyaga a korábban említettekéhez hasonlóan rituális eszközök készítésekor használt.

44 Nyugat-mongóliai, ojrát vonós hangszer. Részletesen lásd Pegg 2001. 


\section{Buddha és a vallás ${ }^{45}$}

Buddhát és a vallást

Szentekhez hívják.

Mások vétett büneit

Buddha vallására bízzuk.

Maitreya nevezetủ buddhát

Homlokon tisztelik.

Megtörtént bünöket

Lámák, kik nekem kedvesek vagytok, rátok bízom.

Ocsir nevezetű buddhát

A fejtetőn tisztelik.

Többség által vétett bünöket

Buddha vallására bízzuk.

Cong kha pa nevezetü buddhát

Fejtetőn tisztelik.

Súlyos bünöket

Buddha vallására bízzuk.

Erőtől duzzadó oroszlán

Zúgva ordítva lendül.

Ember tette bünt

Buddha vallására bízzuk.

\section{Pusztai vörösfenyő}

Puszta közepéből kinövő

Pusztai vörösfenyő magas.

Érzelmeket kényelemmel gyarapító

Szülök.

Mély vízmosás közepéből kinövő

Magányos egyszínű virág.

Magányosan gyermeket szeretetben nevelgető

Szülők.

Repedés közepéböl kinövő

Kétszínü virág.

Kettesben gyermeket szeretetben nevelgető

Szülők.

\section{Burxan šašin xoyor}

Burxan šašin xoyorīg

Bogd dèrē jalna.

Busdīn xīsen xilencīg

Burxan šašindā dātgaya.

Maidar gedeg burxanīg

Magnā dērē jalna.

Magad xīsen xilencīg

Lam tandā dātgana.

Očir gedeg burxanīg

Oroi dērē jalna.

Olonxīn xīsen nügelīg

Burxan šašindā dātgana.

Joxiwā gedeg burxanīg

Julai dērē jalna.

Jujāxan xīsen nügelīg

Burxan šašindā dātgana.

Xüč ixtei arslan

Xüngenen šūgij dewne.

Xünī xīsen nügelīg

Burxan šašindā dātgana.

\section{Sērīn xargai}

Sèr dundāsā urgasan

Sērīn xargai öndör.

Setgel tawār ösgösön

$\bar{E} \bar{a}$ āw xoyor.

Ganga dundāsā urgasan

Gancxan öngīn ceceg.

Ganc durār ni ösgösön

$\bar{E} \bar{a}$ āw xoyor.

Xowil dundāsā urgasan

Xoyorxon öngìn ceceg.

Xoyolangīn ni durārā ösgösön

$\bar{E} \bar{a}$ āw xoyor.

45 A szöveg másik változatát lásd Birtalan 1992. 
Árok közepéből kinövő

Háromszínű virág.

Hármasban gyermeket szeretetben nevelgető

Szülők.

Széles hegynyereg közepéből kinövő

Négyszínü virág.

Négyesben gyermeket szeretetben nevelgető

Szülők.

Mező közepéből kinövő

Ötszínủ virág.

Ötösben gyermeket szeretetben nevelgetö

Szülök.

Szakadék közepéből kinövő

Hatszínü virág.

Hatosban gyermeket szeretetben nevelgető

Szülök.

Domb közepéből kinövő

Hétszínü virág.

Hetesben gyermeket szeretetben nevelgető

Szülők.

Vizenyő közepéből kinövő

Nyolcszínü virág.

Nyolcasban gyermeket szeretetben nevelgetö

Szülök.

Evú ${ }^{46}$ közepéből kinövő

Kilencszínű virág.

Kilencesben gyermeket szeretetben nevelgető

Szülök.

Hegy árnyékos oldalának közepéből kinövő

Tízszínü virág.

Tízesben gyermeket szeretetben nevelgető

Szülök.
Gō dundāsā urgasan

Gurawxan öngīn ceceg.

Gurwūlā tawārā ösgösön

$\bar{E}$ ja $\bar{w}$ xoyor.

Dörölǰ dundāsā urgasan

Dörwön öngìn ceceg.

Dörwūilèg tawārā ösgösön

$\bar{E} \breve{a}$ āw xoyor.

Tal dundāsā urgasan

Tawan öngīn ceceg.

Tawūlāg tawārā ösgösön

$\bar{E} \breve{a}$ āw xoyor.

Jūx dundāsā urgasan

Jurgān öngīn ceceg.

Jurgūlāg tawārā ösgösön

$\bar{E} \breve{a}$ w xoyor.

Dowon dundāsā urgasan

Dolōn öngìn ceceg.

Dolūlāg tawārā ösgösön

$\bar{E}_{j} \bar{a} w$ xoyor.

Nailjag dundāsā urgasan

Naiman öngìn ceceg

Naimūlāg tawārā ösgösön

$\bar{E} \breve{a} \bar{w}$ xoyor

Ewü dundāsā urgasan

Yesön öngīn ceceg.

Yesū̄èg tawārā ösgösön

$\bar{E} \breve{a}$ āw xoyor.

Ar dundāsā urgasan

Arwan öngìn ceceg.

Arwūlāg tawārā ösgösön

$\bar{E} \bar{\jmath} \bar{a} w$ xoyor.

46 A szó jelentését a dolgozat befejezéséig nem sikerült megfejteni. 


\section{Két altáji szülőföld}

Két altáji szülőföld

Barnálló roppantnak látszik.

Két hosúnunkban nekünk

Nincs különbség.

Ezüst zablás fakó

Kíváncsi magabiztossággal jár.

Örök hosúnunkban nekünk

Nincs különbség.

Arany gombod, ha van,

Ne gondold, hogy kigombolódik.

Hasonló ifjainkban nekünk

Nincs különbség.

Ezüst gombod, ha van

Ne gondold, hogy kigombolódik.

Örök hosúnunkban nekünk

Nincs különbség.

Réz gombod, ha van

Ne gondold, hogy kigombolódik.

Szomszédos hosúnunkban nekünk

Nincs különbség.

Északi fenyves

Sárgás-sötétnek látszik.

Apám, anyám

Szinte már látlak titeket.

\section{Trombita szája pecsétes domborodó szemü pej}

$\dot{E} E$ - ÉÉ Trombita szája pecsétes

$E ́ E$ - ÉÉ Domborodó szemü pej.

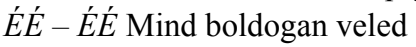

$E_{E} E$ - $E ́ E$ Mulatozva együtt boldogan élünk.

$E ́ E$ - ÉÉ Cintányér szája pecsétes

$\dot{E} E$ - $E ́ E$ Karika szemü pej.

$E ́ E$ - ÉÉ Közösen boldogan veled

$\dot{E} E-E ́ E ́$ Mulatozva együtt boldogan élünk.

\section{Xoyor Altai nutag}

Xoyor Altai nutag

Xürenten dünxīj xaragdana.

Xoyor xošū mand

Yalgamǰ youndā baidīm?

Möngön jūjai šarga ni

Mölöngör dolingor yawdaltai.

Mönx xošū mand

Yalgamǰ youndā baidìm?

Altan towč baiwč

Aldūrna geǰ sanūjai.

Adil jalū mand

Yalgamǰ youndā baidīm?

Möngön towč baiwč

Möltörnö gej sanūjai.

Mönx xošū mand

Yalgamǰ youndā baidīm?

Jes towč baiwč

Jewerne gej sanūjai.

Jergeldē xošū mand

Yalgamǰ youndā baidìm?

Arīn xargai modon

Angirtaj barāntaj xaragdana.

$\bar{a} w$ ēj xoyor mini

Sanagdax č yanjtai.

\section{Bürēgīn aman tamgatai bülger nüden $x \bar{e} r$}

$E E-E E$ Bürēgīn aman tamgatai

$E E-E E$ Bülger nüden xēr.

$E E-E E$ Bügddēn öljītei tantai

EE - EE Nairlan xamt jargana.

EE - EE Cangīn aman tamgatai

EE - EE Cagirag nüden xēr.

EE - EE Cugtān öljītei tantā

EE - EE Nairlan xamt jargana. 
ÉÉ - ÉÉ Kagylókürt szája pecsétes

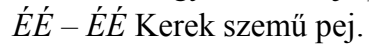

$E ́ E$ - ÉÉ Középen boldogan veled

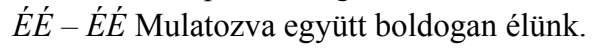

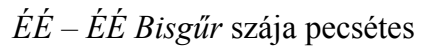

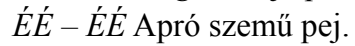

$E ́ E$ - ÉE Minálunk boldogan veled

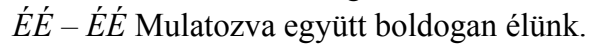

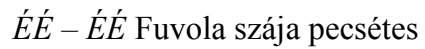

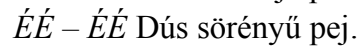

$E ́ E-E ́ E ́$ Teveled boldogan

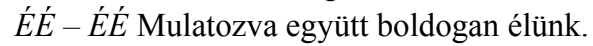

\section{Szürkésfehér ló}

A szürkésfehér ló

Deres, jó húsban van.

Teljesen ösz anyámmal

Egyszer majd találkoznék.

A feketésszürke ló

Jó húsban lévő kövér szokott lenni.

Kán ősz anyámmal

Hazatértemkor jókor találkoznék.

A kékesszürke ló

Jól táplált kövér szokott lenni.

Öreg ösz anyámmal

Odaértemkor jókor találkoznék.

A vörösszürke ló

Öröklődően kövér szokott lenni.

Gyönge ősz anyámmal

Találkánkkor jókor találkoznék.

Magányos öles vörösfenyő

Míg egyedül áll, hajladozik.

Egyetlen kimondott szó

Szívem mélyébe égett.

Párban álló öles vörösfenyő

Míg kettesben áll, hajladozik.

Alig két kimondott szó

Szívem mélyébe égett.
$E E-E E$ Dunginīn aman tamgatai

$E E-E E$ Dugarag nüden xēr.

$E E-E E$ Dundā öljītei tantā

$E E-E E$ Nairlan xamt jargana.

$E E-E E$ Bǐ̌güürn aman tamgatai

$E E-E E$ Bijgen nüdtei xēr.

$E E-E E$ Bidendēe öljìtei tantā

EE - EE Nairlan xamt jargana.

EE - EE Limbin aman tamgatai

$E E-E E$ Lags deltei xēr.

$E E-E E$ Lugtān öljītei tantāa

$E E-E E$ Nairlan xamt Jargana.

\section{Cagān sāral mori}

Cagān sāral mori ni

Cantai targan baina.

Cal būral ējteigē

Cagtā neg l jolgono.

Xar sāral mori ni

Xawtai targan baidag.

Xān būral ējteigēe

Xarixdā neg l jolgono.

Xöx sāral mori ni

Xöntei targan baidag.

Xögšin būral ējteigē

Xürexdē neg l jolgono.

Ulān sāral mori ni

Ultai targan baidag.

Uyan būral èjteigē

Üljaxdā neg l jolgono.

Gancxan jangīn xargai ni

Gancxan boltlō ganxana.

Ganc xelsen üg $n i$

Jürxnī exend uyalgātai.

Xoyorxon jangīn xargai ni

Xoyorxon boltlō ganxana.

Xoyor xelsen üg $n i$

Jürxn̄̄ exend uyalgātai. 
Három öles vörösfenyő

Míg hármasban áll, hajladozik.

Három kimondott szó

Szívem mélyébe égett.

Négy öles vörösfenyő

Míg négyesben áll, hajladozik.

Négy kimondott szó

Szívem mélyébe égett.

Öt öles vörösfenyő

Míg ötösben áll, hajladozik.

Öt kimondott szó

Szívem mélyébe égett.

\section{Galdambá vitéz}

Életed elején

Kérkedvén edzve

Földijeid között

Galdambá vitéz.

Férfinak született

Galdambá vitéz.

(Refrén)

Harmadfü fakó lovat béklyóhoz szoktatott

Alig három ölötöket a háborúban szoktatott. (Refrén)

Negyedfü fakó lovat béklyóhoz szoktatott Alig négy ölötöket a háborúban szoktatott. (Refrén)

Keselyű szárnyát nyila átlőtte

Alig öt őlötöket a háborúban szoktatott.

(Refrén)

Vadszamár lábcsontját nyila eltörte

Alig két őlötöket a háborúban szoktatott.

(Refrén)

Vízmosás kövét nyila szétrepesztette

Alig hat őlötöket a háborúban szoktatott.

(Refrén)
Gurwan jangīn xargai $n i$

Gurawxan boltlo ganxana.

Guraw xelsen $\ddot{u} g \mathrm{ni}$

Jürxnī exend uyalgātai

Dörwön jangīn xargai ni

Döröwxön boltlō ganxana.

Döröw xelsen üg $n i$

Jürxnī exend uyalgātai.

Tawan jangīn xargai ni

Tawxan boltlō ganxana.

Taw xelsen üg $n i$

Jürxnī exend uyalgātai.

\section{Galdambā bātar}

Usnī čini exend

Xanxaljūr soilgōtoi

Ulsin čini dund

Galdambā bātar.

Erlā törsön

Galdambā bātar.

(Daxilt)

Gunan šargīg čödört ni dasgajēe

Gurawxan öldīg daind ni dasgajēe.

(Daxilt)

Dönön šargīg čödört ni dasgajēe

Döröwxön öldīg daind ni dasgajēe.

(Daxilt)

Tasin jüiürrìg tasartal xarwaǰe

Tawxan ōldīg daind ni dasgajēe.

(Daxilt)

Xulangīn čömgīg xugartal xarwaǰe

Xoyorxon öldīg daind ni dasgajēe.

(Daxilt)

Jūxīn čulūg jadartal xarwajē

Jurgāxan ōld̄̄g daind ni dasgajēe.

(Daxilt) 
Domb kövét nyila megrázta

Alig hét őlötöket a háborúban szoktatott. (Refrén)

Mocsár kövét nyila megingatta

Alig nyolc őlötöket a háborúban szoktatott.

(Refrén)

Sarokkövet nyila széttörte

Alig kilenc őlötöket a háborúban szoktatott.

(Refrén)

Rengeteg követ nyila áttörte

Alig tíz ölötöket a háborúban szoktatott.

(Refrén)

Puskagolyók közt küzdő Galdambá.

Harcot bátran váró Galdambá.

Kilött vesszők közt küzdő Galdambá.

Ellenséget bátran váró Galdambá.
Dowongīn čulūg donsoltol xarwaǰe

Dolōxon öld̄̄g daind ni dasgajēe.

(Daxilt)

Namgīn čulūg naigatal xarwajēe

Naimxan ōld̄̄g daind ni dasgajē.

(Daxilt)

Yewügīn čulūg nurtal xarwaǰe

Yesxön ōldīg daind ni dasgaǰē.

(Daxilt)

Arwin čulūg asgartal xarwajēe

Arawxan öldīg daind ni dasgajēe.

(Daxilt)

Būgīn sumār būdalcsan Galdambā.

Būj xülēdeg jorigtoi Galdambā.

Sādagīn sumār būdalcsan Galdambā.

Sātaj xülēdeg jorigtoi Galdambā.

Ez utóbbi dal jól példázza a mongol dicsérő (halha magtāl) dalok kedvelt müfaját, melyben a hős tulajdonságait erősen eltúlozva, himnuszban éneklik meg. ${ }^{47} \mathrm{~A}$ müben feltünik a természeti kép is, valamint jól megfigyelhető az ölötök, vagyis ojrátok számának versszakokat végigkísérő folyamatos emelkedése. A mítosz (halha domog) középpontjában álló Galdambá vitéznek nevezett hős valós történelmi személy. Az ojrátok élén, a mandzsu hódítók ellen küzdő Galdan bosigt kán képe jelenik meg benne, akit az 1696 tavaszán, a mai Ulánbátorhoz közeli Dzún mod mellett vívott csata során győztek le végleg. A vereség után megmaradt serege is lassan elhagyta egykori vezérét, aki ekkor, a mandzsu seregtől üldözve 1697. március 13-án méreggel vetett véget saját életének. ${ }^{48}$

\section{Távolból futó aranysárga ló}

Távolból futó

Aranysárga ló.

Kocsijába befogó szentség

Naphoz méltóan vonul.

\section{Gajrīn xolōs güideltei altan šarga mori}

Gajrīn xolōs güideltei

Altan šarga mori.

Tünīg xölöglögč bogd

Naran met jalarna.

47 Lörincz 1969: 140-147, Birtalan 1992.

48 Baabar 2005: 83-84. 
Négyoroszlános trónt

Nyugodtként tisztelik.

Negyvenezer tanítvány

Dansig ünnepet ${ }^{49}$ tartva imádkozik.

Nyolcoroszlános trónt

Békésként tisztelik.

Nyolcvanvenezer tanítvány

Dansig ünnepet tartva imádkozik.

Északi folyó forrásánál

Aranyos trombitát fújnak.

Százezer tanítvány

Dansig ünnepet tartva imádkozik.

Déli folyó forrásánál

Vörös trombitát fújnak.

Sokezernyi tanítvány

Dansig ünnepet tartva imádkozik.

Fehér folyó forrásánál

Hó kürtjét fújják.

Ez idei sok tanítvány

Dansig ünnepet tartva imádkozik.

Távolból futó

Bársonyfekete lóra.

A távolból gondolva

Aranyos oszlop anyjának tünik.

Négyoroszlános trónt

Ne gondold nyugodtnak.

Negyvenezer ölötöt

Ne gondold kevésnek.

Nyolcoroszlános trónt

Ne gondold alacsonynak.

Nyolcvanezer ölötöt

Ne gondold kevésnek.
Dörwön arslantai širēg

Dülgülen gej jalna.

Dörwön tümen šawi nar

Danšgā örgōd mörgönö.

Naiman arslantai širēg

Namūxan gě jallā.

Naiman tümen šawi nar

Danšgā örgōd mörgönö.

Ar golīn exend

Altan bürēgē tatna.

Arwan tümen šawi nar

Danšgā örgōd mörgönö.

Urd golīn exend

Ulān bürēgè tatna.

Olon tümen šawi nar

Danšgā örgōd mörgönö.

Cagān golīn exend

Casan bürēgè tatna.

Cagīn olon šawi nar

Danšgā örgōd mörgönö.

Gajrīn xolōs güideltei

Xilen xar mori.

Gajrīn xolōs sanagddag

Altan bagana ēj.

Dörwön arslantai širēg

Dölüxen geǰ sanūjai.

Dörwön tümen ōlddīg

Cön geǰ sanūjai.

Naiman arslantai širēg

Namxan geǰ sanüjai.

Naiman tümen öldīg

Cön geǰ sanūjai.

49 Többek között buddhista szentek reinkarnációinak tartott gyermekeknek bemutatott áldozati szertartás. Bővebben lásd Birtalan 1992. 
$K_{\text {Kulán }}{ }^{50}$ és $t a k i^{51}$ csikója

Kerekded patája kinő.

Három folyót átszelve

Vad alakját eléri.

Hattyú fiókái

Szárnyán tolla kinő.

Három tengert átszelve

Úszósok rangját elérik.

\section{A Mindzsit Hángáj szarvasa}

Mindzsit Hángáj szarvasa

Ringatózva, ingadozva bőg.

Mikor rólam merengesz

Mindzsit őrségéhez látogass.

Hándzsit Hángáj szarvasa

Tiszta éles hangon bőg.

Mikor szeretőn rám gondolsz

Hándzsit őrségéhez látogass.

Hurin Hángáj szarvasa

Távolba vesző hangon bőg.

Mikor rám emberként gondolsz

Hunhgir őrségéhez látogass.

Élen járó málhahordó

Szelíd deres ló.

Vétkest és ártatlan

Szemed pillantásával ismerj fel.

Terhet vivő málhahordó

Tarka színü ló.

Veszélyest és békést

Tarka szemeddel megláss.

Poroszkálva lépésben járó

Csinos pej ló.

Ártalmast és ártalmatlant

Váratlant kérdezve ismerj fel.
Xulan taxīn unaga

Xumban tūraigā güicēgēd.

Gurwan golīg gatalj

Adgūs šinǰ̄̆g olno.

Xun cengīn degdèmel

Öd jigü̈rēn güicēj.

Gurwan dalaig gatalj

Jiwerten colīg olno.

\section{Minjit xangain buga}

Minjit xangain buga

Mēxeljtel mēxeljtel uramdana.

Melmeger namaigā gexlēr

Minjintīn xarūlār dairāăc.

Xanjit xangain buga

Xanxintal xanxintal uramdana.

Xairtai namaigā gexēr

Xanjitīin xarūlār dairāč.

Xüren xangain buga

Xüngentel xüngentel uramdana.

Xümerleg namaigā gexēr

Xünxgerīn xarūlār dairāč.

Nüdlīn türünd unadag

Nomgon bor morin.

Nügeltei nügelgüi xoyorig

Nüdīnxē xarcār medērei.

Ačāni türünd unadag

Alag jüstei morīn.

Ayūltai ayūlgüi xoyorīg

Alag nüdèrē medèrei.

Gišgelden gišgelden yawdag

Gangan xēr morīn.

Gemtei gemgüi xoyorīg

Gentgen asūgād medērei.

50 Mára erősen megritkult egyedszámú, ázsiai vadszamárfajta (Equus hemionus kulan).

51 Ázsiában honos, veszélyeztetett, vadon élő Przsevalszkij-ló (Equus przewalskii). 
Nádszínü, fekete sörényüt $t^{52}$

Villám fürgének mondják.

Patkány évű jómagamat

Hozzá illőnek mondják.

Vadló színü fekete sörényüt

A Tahilt [áldozóhelyes] hegyháton eddzed.

Tyúk évü jómagamat

Tahilt örségében látogass meg.
Xulsan öngötei xulīg

Xurdan xurdan gelcnē $l$.

Xulgan jiltei namaig

Iwēl iwēl gelcnē l.

Taxi jüstei xulig

Taxiltīn šild soigōč.

Taxia juiltei namaigā gewel

Taxiltīn xarūlār dairāè.

E domog - felgyüjtőjének lejegyzése szerint - egy helyi fiatal pár történetét meséli el. ${ }^{53}$ Volt egyszer egy ifjú pár, akik mindennél jobban szerették kedves szülőföldjüket. A lány a szállás körüli különböző kézimunkákban jártas, szavaiban bölcs, ráadásul páratlan szépségű menyecske volt. A helyi hosún ura ezt megirigyelve, a lány kedvesét erőszakkal a távoli határőrség katonái közé kényszerítette, hogy asszonyát saját feleségévé tegye. A lány azonban a kényszerházasság helyett inkább a halált választotta, és a Mindzsit Hángáj-hegyre felmenve önkezével vetett véget életének. Azóta bárki emberfia járjon is azon a helyen, mindig hallja az elmúlt leány tisztán csengő énekét, ezért az emberek lassan kerülni kezdték a helyet. Mikor kedvesének szomorú vége szeretője fülébe jutott, súlyos gyász terhe telepedett szívére. Lova nyergébe ülve estefelé felment a Mindzsit Hángáj csúcsára, ahol kedvese egy ragyogóan fehér, új jurtából kilépve üdvözölte őt. Megosztotta vele minden örömét és bánatát, majd amikor késői órán lefekvéshez készülődtek, így szólt:

- Mivel én már nem ehhez a világhoz tartozom, ez lesz ma az utolsó alkalom, hogy láthatjuk egymást. Mikor reggel felébredsz, egy csésze fog várni rád. Mielőtt elmennél, fenékig idd ki!

Hajnalodván a fiú felébredt, de szerelme helyett csak egy csésze kancatejet talált. Azonban, amint megitta volna, különös érzés fogta el, ezért csupán elrakta az italt, és távozott. Ezt követően a leány éneke elhallgatott a hegyoldalon, a tejjel készült fehér ételek sorából pedig a környéken élők elhagyták a kumiszt.

A dallal kapcsolatban élő dzahcsin szokás, hogy azt esküvőkön nem éneklik, azonban más ünnepségeken hallható.

52 A jószág színére használt szó. Fekete sörényủ és farkú, gerincén sötét csíkot viselő fakó vagy sárga ló.

53 Dügersüren 1992: 56-57. 


\section{Összegzés}

A fent idézett néhány dal csupán kis hányada az általam gyüjtötteknek, így ezekből messzemenő következtetéseket levonni nem merek, különös tekintettel az előszóban leírtakra, vagyis, hogy a jelen írás csupán előfutára egy nagyobb szabású, összefoglaló munkának, melyröl röviden írni nem lehetséges. A jövőben a fordítást és a publikálást folytatni kívánom, illetve más énekesekkel is interjút szeretnék készíteni a fővárosban és Hovd megyében egyaránt, ami után az így kibővített anyag párhuzamos szövegekkel való összevetéséről is írni kívánok.

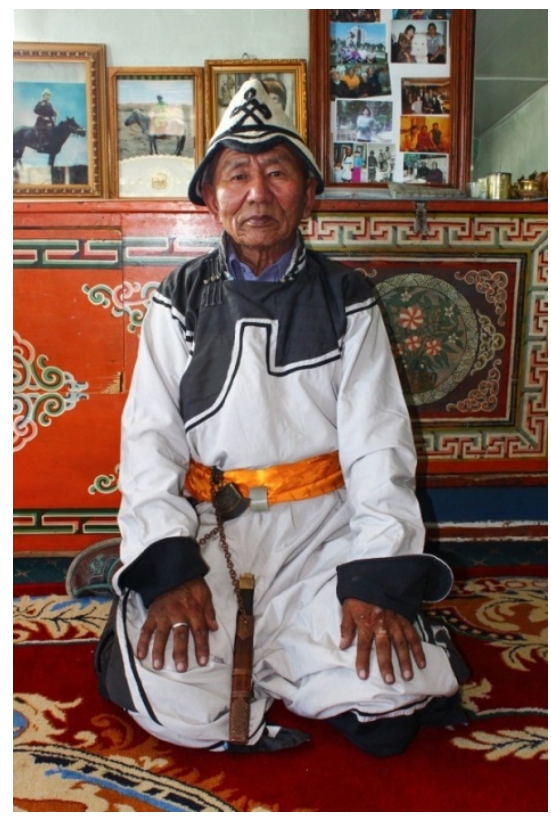

Dzahcsin népdalénekes, Cs. Dügersüren, hagyományos öltözékében - Hovd megye, Altaj szum, 2015 augusztus (a szerző felvétele)

\section{Elsődleges források}

Badamxatan, S. (szerk.) 1996. Mongol ulsīn ugsātnī jüi [Mongólia néprajza]. [Oiradīn ugsātnī jüi: XIX.] Ulānbātar, s.n.

Batubayar, Ba 2013. Jaqačin-u teüke soyul-un sudulul [Dzahcsin történelem- és müveltségkutatás]. [Oyirad mongyol-un teüke soyul-un čuburil bičig 10. S. 1.] Ürümqi: Sin- 
jiyang-un Arad-un Kebel-ün Yerüngkei Qoriy-a - Sinǰiyang-un Arad-un Kebel-ün Qoriy-a.

Colō, J̆. 1988. BNMAU daxi mongol xeln̄̄ nutgīn ayalgūn̄̄ toli bičig II. Oird ayalgū [A Mongol Népköztársaságbeli mongol nyelv nyelvjárási szótára]. Ulānbātar: s.n.

Dügersüren, Č. 1992. Jaxčin ardīn urtīn dīnī tüwwer [Dzahcsin népi hosszúdalgyüjtemény]. Altai sum: s.n.

Xün am, oron sūcnī 2010 onī ulsīn tōllogo: negdsen dün [Népesség, lakáshelyzet 2010 évi országos népszámlálása: összesített eredmény]. (Online elérhetőség: http://ubstat.mn/ News=ebaf41a3-0bff-11e1-9add-001fc60e81da. "BCI" Xewlelīn kompani, Ulānbātar xot, 2011 on., 51-63. [Utolsó megtekintés: 2015.09.24.])

\section{Másodlagos szakirodalom}

Atwood, P. Christopher 2004. Encyclopedia of Mongolia and the Mongol Empire. Bloomington Indiana: Indiana University.

Baabar, Bat-Erdenīn 1999. History of Mongolia. Cambridge: White Horse Press.

Baabar, Bat-Erdenīn 2005. History of Mongolia. Monsudar.

Birtalan, Ágnes 1985. „Geschichte der heiligen Götterbilder der drei Klöster unseres Jaqačin Volks.“ Acta Orientalia Hung. 39: 177-203.

Birtalan Ágnes 1992. Egy századeleji nyugat-mongol népdalgyüjtés müfajai és nyelve. (kandidátusi értekezés, kézirat)

Birtalan Ágnes 2001. Wörterbuch der Mythologie der mongolischen Volksreligion. [Wörterbuch der Mythologie 34. Ed. Egidius Schmalzriedt - Hans W. Haussig.] Stuttgart: Klett-Cotta Verlag, 879-1097.

Birtalan Ágnes 2004. „A Föld és a Víz gazdaszellemeinek kultusza a nyugat-mongóliai zahcsinoknál.” In: Birtalan Ágnes (szerk.) Helyszellemek kultusza Mongóliában. Budapest: Új Mandátum, 51-68.

Birtalan Ágnes 2005. „Oirat.” In: Juha Janhunen (ed.) The Mongolic Languages. Taylor - Francis e-Library, 210.

Birtalan Ágnes 2008. „Nyugat-mongol (dzahcsin) buddhista népdalok.” Keréknyomok 2008/tél: 27-31.

Birtalan Ágnes 2012. Oirad and Kalmyk Linguistic Essays. (Tálentum sorozat 11.) Budapest: Eötvös Kiadó.

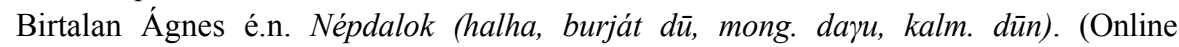
elérhetőség: http://gepeskonyv.btk.elte.hu/adatok/Okor-kelet/Okori.es.keleti.irodalmak/ index.asp_id=738.html. [Utolsó letöltés: 2015.11.05]

Birtalan Ágnes - Rákos Attila 2002. Kalmükök - Egy európai mongol nép. (TEXTerebess 1.) Budapest: Terebess Kiadó.

Colō, J̆. 1987. Arwan gurwan xülgīn dūn. Oird aman joxiolīn comorlog [Tizenhárom hátas dala. Ojrát népköltészet gyüjteménye]. Ulānbātar: Улсын Хэвлэлийн Газар. 
Kara, György 2005. Books of the Mongolian Nomads. More Than Eight Centuries of Writing Mongolian. Bloomington, Indiana: Indiana University, Research Institute for Inner Asian Studies.

Kara György 1998. Mongol-magyar kéziszótár. Budapest: Terebess Kiadó.

Lőrincz László 1969. A mongol népköltészet. [Ligeti Lajos (szerk.): Körösi Csoma Kiskönyvtár 6.] Budapest: Akadémiai Kiadó. (online elérhetőség: http://mek.oszk.hu/ 09700/09786/html/, utolsó megtekintés: 2015.11.06.)

Pegg, Carol 2001. Mongolian Music, Dance - Oral Narrative. Seattle - London: University of Washington Press. 